1 Brock, T. D., Science, 158, 1012 (1967).

2 Brock, T. D., in Microbial Growth, Nineteenth Symp. Soc. Gen. Microbiol., 15 (Cambridge University Press, 1969).

3 Brock, T. D., and Darland, G. K., Science, 169, 1316 (1970).

4 Bott, T. L., and Brock, T. D., Science, 164, 1411 (1969).

5 Bott, T. L., and Brock, T. D., Limnol. Oceanog., 15, 333 (1970).

6 Brock, T. D., Brock, M. L., Bott, T. L., and Edwards, M., J. Bact. (in the press).

7 Brock, T. D., and Brock, M. L., New Zealand J. Marine Freshwater Res. (in the press).

${ }^{8}$ Castenholz, R. W., Bact. Revs., 33, 476 (1969).

\section{Potential Cocarcinogenicity of Sodium Hypochlorite}

SoDium hypochlorite has been widely used as a bleaching agent and disinfectant. No particular hazard of this chemical to man has been recognized (see, for example, ref. 1) except for the poisoning of infants by the accidental ingestion of concentrated solution. We now report, however, that sodium hypochlorite is definitely concerned in cancer production in mice as a cocarcinogen ${ }^{2-4}$.

In testing for cocarcinogenicity, a group of animals is treated with a potent carcinogen in a dose which by itself is not enough to produce a cancer. A suspected chemical cocarcinogen is also given to the same animals, either before or after. The development of a cancer offers a sensitive test for potentially carcinogenic compounds ${ }^{5 \sim 7}$.

A commercial sodium hypochlorite solution which contained more than $10 \%$ effective chlorine was used. The carcinogen selected was 4-nitroquinoline 1 -oxide ${ }^{8,9}$. The mice were ddN strain females maintained on water and a standard pellet diet. Before the application of the chemicals, hair was clipped off over an area $1 \mathrm{~cm}$ in diameter in the interscapular region where the chemicals were applied.

Three groups of forty 5 week old mice were used. One group was used in a combination experiment.

Twenty applications of 4-nitroquinoline 1-oxide alone produced neither malignant nor benign tumours. Although hypochlorite did not induce skin tumours by itself in sixty applications, skin tumours were induced in nine of thirty-two mice by forty-five applications given after submanifestational doses of 4-nitroquinoline 1-oxide. Thus, one fibrosarcoma of the skin and three squamous cell carcinomas were produced after about 240 days. Five papillomas remained until the end of the experiment. In one tumour-bearing mouse metastases to lung and kidney were observed. Besides the skin tumours, one lymphatic leukaemia was found in another mouse about 360 days after the start of the experiment. No tumours resulted from sixty paintings of aqueous sodium hydroxide at $p \mathrm{H}$ $11 \sim 12$ combined with twenty applications of 4-nitroquinoline 1-oxide, indicating that potential carcinogenicity of hypochlorite solution is due to the hypochlorite itself and not to the alkalinity of the solution.

Solutions of sodium hypochlorite containing approximately $5 \%$ chlorine are available commercially and used widely. For bleaching, the solution is diluted up to several hundred times. Various materials, including foods, may be sterilized using a solution diluted several hundred times. Drinking water may be disinfected by a low concentration of chlorine $(0.1$ to several parts per million). In the treatment of some skin diseases caused by fungi, a dilute solution may be applied directly to the diseased part. Although in such conditions it seems unlikely that this common chemical constitutes a practical carcinogenic hazard, the data presented here provide a caution against its indiscriminate use.

We thank Dr W. Nakahara, director of the National Cancer Center Research Institute, for valuable discussion and pathological diagnosis and Professor T. Ukita of the Faculty of
Table 1 Carcinogenicity of Sodium Hypochlorite in Mice when Combined with a Submanifestational Dose of Carcinogenic 4-Nitroquinoline 1-Oxide

\begin{tabular}{|c|c|c|c|c|}
\hline \multirow[b]{3}{*}{ Group 1} & \multirow{3}{*}{$\begin{array}{l}\text { No. of } \\
\text { mice } \\
32\end{array}$} & \multicolumn{2}{|c|}{ Skin tumours } & \multirow{3}{*}{$\begin{array}{c}\text { Leukaemia } \\
1\end{array}$} \\
\hline & & $\begin{array}{l}\text { Malignant } \\
\text { (No. } \mathrm{O}\end{array}$ & $\begin{array}{l}\text { Benign } \\
\text { ice) }\end{array}$ & \\
\hline & & 4 & $5(1)$ & \\
\hline Group 2 & 29 & 0 & 0 & 0 \\
\hline Controls & 27 & 0 & 0 & 0 \\
\hline
\end{tabular}

The potent carcinogen was first painted on in twenty applications of $0.05 \mathrm{mg}$ in $0.25 \%(\mathrm{w} / \mathrm{v})$ benzene solution ${ }^{5}$ in the course of 50 days $(1.0 \mathrm{mg} / \mathrm{mouse}$ in total). Six days after the end of this treatment, one drop (about $0.05 \mathrm{ml}$.) of the hypochlorite solution was painted on and repeated forty-five times during 245 days (group 1). Other mice (group 2) were treated only with 4-nitroquinoline 1-oxide. The control mice were treated only with the hypochlorite (sixty times in 300 days). All of the mice treated were observed for 450 days from the start of the experiment.

The number in the parentheses shows the number of papillomas that regressed.

Pharmaceutical Sciences, University of Tokyo, and Dr F. Fukuoka of the National Cancer Center Research Institute for research facilities.

Faculty of Pharmaceutical Sciences,

Hikoya Hayatsu

University of Tokyo,

Bunkyo-ku, Tokyo

Department of Radiology,

School of Medicine,

Keio University,

Shinano-cho,

Shinjuku-ku, Tokyo

National Cancer Center Research Institute,

Yutaka Kawazoe

Tsukiji,

Chuo-ku, Tokyo

Received June 21, 1971.

1 Druckrey, H., Food Cosmet. Toxicol., 6, 147 (1968).

2 Nakahara, W., Prog. Exp. Tumour Res., 2, 168 (1961).

3 Druckrey, H., and Küpfmüller, K., Z. Naturforsch., 3b, 254 (1948).

4 Berenblum, I., Prog. Exp. Tumour Res., 11, 21 (1969).

5 Hoshino, H., Tanooka, H., and Fukuoka, F., Gann, 59, 43 (1968).

${ }^{6}$ Hoshino, H., Kawazoe, Y., and Fukuoka, F., Gann, 60, 523 (1969).

7 Hoshino, H., Chihara, G., and Fukuoka, F., Gann., 61, 121 (1970).

${ }^{8}$ Nakahara, W., Fukuoka, F., and Sugimura, T., Gann, 48, 129 (1957).

9 Ochiai, E., J. Org. Chem., 18, 549 (1953).

\section{Hormonal Pregnancy Tests and Neural Tube Malformations}

IN 1967 Gal, Kirman and Stern ${ }^{1}$ reported a possible relationship between pregnancy tests using pills containing synthetic oestrogenic and progesterogenic hormones and the birth of a child with spina bifida. Of the 100 mothers of children with spina bifida, nineteen gave a history of pregnancy diagnosis by this means; only four of the 100 matched control mothers gave such a history.

A similar retrospective enquiry has been made between 1968 and 1970 in three centres, but including births of the clearly related malformation anencephaly as well as spina bifida. In the London series the control mothers were those having the next baby born in the same hospital. In the Exeter series the control mothers were matched for area of birth, 